\title{
Kontrola celno-skarbowa w obrocie między Unią Europejską a krajami trzecimi
}

\section{Streszczenie}

W wyniku przeprowadzonej w 2017 roku reformy w miejsce dotychczas funkcjonujących administracji podatkowej, kontroli skarbowej i Służby Celnej powołano Krajową Administrację Skarbową, konsolidując w ten sposób administrację skarbową. Chociaż skuteczność poboru podatku VAT, akcyzy oraz opłaty paliwowej wzrosła, istnieją jeszcze obszary wymagające analizy zakresu definicyjnego, statystycznego, prawnego oraz zwiększenia skuteczności egzekwowania przepisów celno-podatkowych zarówno Unii Europejskiej, jak i polskich.

Celem artykułu jest analiza funkcjonowania obowiązujących od 1 marca $2017 \mathrm{r}$. regulacji dotyczących kontroli celno-skarbowej pod kątem wymiaru i poboru przez nowe organy należności związanych z przywozem i wywozem towarów na obszar celny Unii Europejskiej.

Słowa kluczowe: Krajowa Administracja Skarbowa, kontrola celno-skarbowa, akcyza, opłata paliwowa, podatek VAT

Anna Reiwer-Kaliszewska - Wyższa Szkoła Administracji i Biznesu im. E. Kwiatkowskiego, w Gdyni; e-mail areiwer@yahoo.co.uk; ORCID: 0000-0002-6724-8137.

2 Tomasz D. Nowak-Opolski Urząd Celno-Skarbowy w Opolu; e-mail tomasz.nowak3@mf.gov.pl; ORCID 0000-0001-6022-9139. 


\title{
Customs and Tax Inspection in Trading between the European Union and Third Party Countries
}

\begin{abstract}
As a result of a reform implemented in 2017, the National Revenue Administration ${ }^{3}$ was established in place of the existing tax administration, tax inspection, and the Customs Service. The tax administration was consolidated this way. Although the efficiency of collecting VAT, excise tax and fuel duty increased, there are still areas which require an analysis of the definition, statistical and legal scope, and an increase in the efficiency of enforcing compliance with both the European Union's regulations on customs and tax and the Polish ones. The purpose of this paper is to analyse the functioning of regulations which have been applicable since 1 March 2017 and which concern customs and tax inspection of the assessment and collection of charges, which are related the import and export of goods onto the customs territory of the European Union, by the new authorities.
\end{abstract}

Keywords: National Tax Administration, customs and tax control, excise tax, fuel tax, VAT

3 In Polish: Krajowa Administracja Skarbowa [translator's note]. 


\section{Wprowadzenie}

Wymiar i pobór należności celnych oraz innych opłat związanych z przywozem i wywozem towarów, podatku od towarów i usług z tytułu importu towarów oraz podatku akcyzowego i opłaty paliwowej należał przed dniem 1 marca 2017 r. do zadań Służby Celnej ${ }^{4}$. Były to "tradycyjne” i z punktu widzenia ekonomicznych interesów państwa, najbardziej istotne obszary jej działalności. Poszerzenie uprawnień Służby Celnej o wymiar i pobór podatku od towarów i usług z tytułu importu towarów oraz kontroli, szczególnego nadzoru podatkowego, a także wymiar i pobór akcyzy, a za nią opłaty paliwowej, przypisane zostały organom celnym dopiero od 1 września 2003 roku. Przed tym dniem pobór tych danin należał do kompetencji naczelników urzędów skarbowych ${ }^{5}$. Celem tej zmiany było zbliżenie, w przededniu akcesji do UE, organizacji i kompetencji administracji skarbowej do standardów stosowanych w krajach Unii Europejskiej ${ }^{6}$. Rozwiązanie to, faktycznie dominujące w krajach członkowskich, jest konsekwencją konstrukcji tego podatku wzorowanej na regulacjach prawa celnego ${ }^{7}$.

Realizacji wymienionych zadań służyły w szczególności czynności kontrolne wykonywane przez naczelników urzędów celnych i dyrektorów izb celnych - w zależności od przedmiotu kontroli - na podstawie przepisów ustawy o Służbie

$4 \quad$ Przepisy unijnego prawa celnego dopuszczają możliwość ustanowienia tzw. ceł wywozowych. Dotychczas takie cła nie zostały przez UE ustanowione.

5 Artykuł 34a ustawy z dnia 8 stycznia 1993 r. o podatku od towarów i usług oraz o podatku akcyzowym regulujący właściwość organów w akcyzie dodany został do ustawy na podstawie art. 11 pkt 21 ustawy z dnia 27 czerwca 2003 r. o utworzeniu Wojewódzkich Kolegiów Skarbowych oraz o zmianie niektórych ustaw regulujących zadania i kompetencje organów oraz organizację jednostek organizacyjnych podległych ministrowi właściwemu do spraw finansów publicznych (Dz. U. z 2003 r. Nr 137, poz. 1302 ze zm.).

6 Zob. uzasadnienie do projektu ustawy z dnia 27 czerwca 2003 r. o utworzeniu Wojewódzkich Kolegiów Skarbowych oraz o zmianie niektórych ustaw, http://orka.sejm.gov.pl/Druki4ka.nsf/ (\$vAllByUnid)/248EE1CC2E96266CC1256C54002629C0/\$file/991_01.pdf, dostęp: 9 października $2018 \mathrm{r}$.

7 Zob. K. Piech, Procedura tranzytu jako pierwowzór procedury zawieszenia poboru akcyzy. O zwiazkach prawa akcyzowego z prawem celnym na podstawie doświadczeń niektórych państw członkowskich Unii Europejskiej (w:) Prawo celne i podatek akcyzowy. Kierunki przeobrażeń i zmian, red. P. Stanisławiszyn, T. Nowak, Warszawa 2014, s. 360-381. 
Celnej $^{8}$ (w przypadku importu i eksportu) lub na zasadach określonych w Dziale VI Ordynacji podatkowej (w odniesieniu do podatku akcyzowego i opłaty paliwowej w obrocie krajowym oraz pomiędzy państwami członkowskimi UE) ${ }^{9}$. Kontrolę w zakresie należności celnych i innych opłat związanych z przywozem i wywozem towarów oraz podatków z tytułu importu i eksportu towaru, a także podatku akcyzowego i opłaty paliwowej wykonywał również dyrektor urzędu kontroli skarbowej na podstawie przepisów ustawy z dnia 28 września 1991 r. o kontroli skarbowej ${ }^{10}$.

Zasady kontroli przywozu towarów na obszar celny Unii Europejskiej i wywozu z tego obszaru (do 1 maja 2004 r. dotyczyło to obszaru celnego Rzeczpospolitej Polskiej) oraz kontroli towarów polegających kontyngentom ilościowym, akcyzie i opłacie paliwowej były więc regulowane przez trzy odrębne ustawy, stosowane przez działających niezależnie, choć współpracujących ze sobą, naczelników urzędów celnych i dyrektorów izb celnych oraz dyrektorów urzędów kontroli skarbowej.

Z dniem 1 marca 2017 r. weszła w życie ustawa o Krajowej Administracji Skarbowej $^{11}$ (dalej: ustawa o KAS). Utraciły moc ustawa o Służbie Celnej oraz ustawa o kontroli skarbowej. Wymienione wyżej organy zostały zniesione ${ }^{12}$. W ich miejsce powołani zostali naczelnicy urzędów celno-skarbowych i dyrektorzy izb administracji skarbowej. Zgodnie z art. 2 ust. 1 pkt 1 i 2 ustawy o KAS do podstawowych zadań KAS należy realizacja dochodów z podatków, opłat oraz niepodatkowych należności budżetowych, jak również innych należności, na podstawie odrębnych przepisów, z wyjątkiem podatków i należności budżetowych, w zakresie których właściwe są inne organy oraz realizacja dochodów z należności celnych oraz innych opłat związanych z przywozem i wywozem towarów.

Z preambuły do ustawy o KAS wynika również, iż przyjmując ten akt, ustawodawca kierował się troską o bezpieczeństwo finansowe Rzeczpospolitej Polskiej i miał jednocześnie na uwadze ochronę bezpieczeństwa obszaru celnego Unii Europejskiej.

Tak znaczące zmiany w działalności organów odpowiedzialnych za bezpieczeństwo finansowe państwa uzasadniają ocenę ich funkcjonowania w świetle

8 Zob. art. 2 ust. 1 pkt 2, ust. 2, ust. 4 ustawy z dnia 27 sierpnia 2009 r. o Służbie Celnej (tekst jedn. Dz. U. z 2016 r., poz. 1799 ze zm.).

9 Ustawa z dnia 29 sierpnia 1997 r. - Ordynacja podatkowa (tekst jedn. Dz. U. z 2018 r., poz. 800 ze zm., dalej: o.p.).

10 Zob. art. 2 ust. 1 pkt 1 i 12 ustawy z dnia 28 września 1991 r. o kontroli skarbowej (tekst jedn. Dz. U. z 2016 r., poz. 720 ze zm.).

11 Tekst jedn. Dz. U z 2018 r., poz. 508 ze zm., dalej ustawa o KAS.

12 Zob. art. $159 \mathrm{i}$ art. 160 ustawy z dnia 16 listopada 2016 r. - Przepisy wprowadzające ustawę o Krajowej Administracji Skarbowej (Dz. U. poz. 1948 ze zm.). 
ponaddwuletnich doświadczeń. Ze względu na przyjęte ramy publikacji autorzy koncentrują swoją analizę na funkcjonowaniu obowiązujących od 1 marca 2017 r. regulacji pod kątem wymiaru i poboru przez nowe organy należności związanych z przywozem i wywozem towarów na obszar celny Unii Europejskiej. W świetle przewidywanego wyjścia Wielkiej Brytanii z Unii Europejskiej i prawdopodobnego w związku z tym wzrostu liczby dokonywanych zgłoszeń celnych problematyka ta, niezależnie od intencji piszących, stanie się zagadnieniem dotyczącym znacznie większego kręgu podmiotów niż dotychczas.

\section{Unijny kodeks celny i uregulowania dotyczące obszaru celnego UE oraz zadań organów celnych}

Przez obszar celny Unii Europejskiej należy rozumieć terytoria wraz z ich wodami terytorialnymi, wodami wewnętrznymi oraz przestrzenią publiczną enumeratywnie wymienione w art. 4 Unijnego Kodeksu Celnego ${ }^{13}$ (dalej UKC). Tam też zawarto wyłączenia terytoriów niewchodzących w skład unijnego obszaru celnego. Podkreślić należy, że terytoria poszczególnych państw członkowskich nie są tożsame z obszarem celnym Unii Europejskiej. Podobnie do obszaru celnego Unii Europejskiej mogą należeć terytoria, które nie wchodzą w skład poszczególnych państw członkowskich. W przypadku Rzeczpospolitej Polskiej całe jej terytorium wchodzi od 1 maja 2004 r. w skład unijnego obszaru celnego.

Zadania organów celnych określone zostały w art. 3 UKC, zgodnie z którym są one odpowiedzialne za nadzór nad międzynarodową wymianą handlową Unii Europejskiej, wspierając w ten sposób sprawiedliwy i swobodny handel, wdrażanie zewnętrznych aspektów rynku wewnętrznego, wspólnej polityki handlowej oraz pozostałych wspólnych polityk Unii w zakresie wymiany handlowej, a także bezpieczeństwo całego łańcucha dostaw. Organy celne wyposażone są w kompetencje do wprowadzenia środków mających na celu w szczególności:

a) ochronę interesów finansowych Unii i jej państw członkowskich;

b) ochronę Unii przed nieuczciwym i nielegalnym handlem przy równoczesnym wspieraniu legalnej działalności gospodarczej;

c) zapewnianie bezpieczeństwa i ochrony Unii i jej mieszkańców oraz ochrony środowiska, w stosownych przypadkach w ścisłej współpracy z innymi organami oraz

13 Rozporządzenie Parlamentu Europejskiego i Rady (UE)nr 952/2013 z dnia 9 października 2013 r. ustanawiające unijny kodeks celny (wersja przekształcona), Dz.U. UE L.2013.269.1. 
d) utrzymanie należytej równowagi pomiędzy kontrolami celnymi a ułatwieniami legalnej wymiany handlowej, m.in. w ramach kontyngentów ilościowych.

\section{Definicja i zakres kontroli celno-skarbowej}

W ustawie o Krajowej Administracji Skarbowej brakuje legalnej definicji kontroli celno-skarbowej. Trafną definicję zaproponował A. Melezini ${ }^{14}$, którego zdaniem kontrola celno-skarbowa stanowi „szczególnego rodzaju procedurę administracyjną o charakterze policyjnym". Jest to regulowany przepisami ustawy ciąg czynności, które są podejmowane przez jej uczestników. Procedura ta zapoczątkowana zostaje upoważnieniem organu celno-skarbowego, a kończy się wydaniem przez ten organ rozstrzygnięcia $w$ formie wyniku kontroli lub protokołu ${ }^{15}$.

Zakres przedmiotowy kontroli celno-skarbowej jest bardzo pojemny. Oparty został na obowiązujących przed 1 marca 2017 roku regulacjach zawartych w ustawie o kontroli skarbowej oraz w ustawie o Służbie Celnej. Zgodnie z art. 54 ust. 1 artykułu ustawy o KAS kontroli celno-skarbowej podlega między innymi przestrzeganie przepisów prawa podatkowego w rozumieniu art. 3 pkt 2 Ordynacji podatkowej (czyli przepisów ustaw podatkowych, postanowień ratyfikowanych przez Rzeczpospolitą Polską umów o unikaniu podwójnego opodatkowania oraz ratyfikowanych przez Rzeczpospolitą Polską innych umów międzynarodowych dotyczących problematyki podatkowej, a także przepisów aktów wykonawczych wydanych na podstawie ustaw podatkowych), przestrzeganie przepisów prawa celnego oraz innych przepisów związanych z przywozem i wywozem towarów w obrocie między obszarem celnym Unii Europejskiej a państwami trzecimi, jak również przepisów regulujących urządzanie i prowadzenie gier hazardowych, przepisów prawa dewizowego oraz przepisów o przeciwdziałaniu praniu pieniędzy oraz finansowaniu terroryzmu. Istotnym zagadnieniem kontroli ilościowej w prawie celnym jest konieczność egzekwowania przez KAS rzeczywistej ilości paliwa, które jest przywożone do Polski z państw trzecich, przeważnie ze wschodu, w standardowych zbiornikach samochodów. Zamiast jednorazowej liczby 200 litrów, która jest zwolniona od podatku na podstawie ustawy o podatku akcyzowym służby odnotowują liczne przypadki przewozu ponad 600 litrów, co wymaga pilnego zakończenia prac nad projektem zmiany ustawy z dnia 19 marca 2004 r.

\footnotetext{
14 A. Melezini, w: Krajowa Administracja Skarbowa. Komentarz, red. A. Melezini, K. Teszner, Wolters Kluwer, Warszawa 2018, s. 235.

15 Ibidem.
} 
- Prawo celne (Dz. U. z 2004 r. poz. 622) ${ }^{16}$. Obecnie powyższa luka daje zbyt duże możliwości nielegalnego importu paliw, którego sprzedaż daje wpływy szarej strefie.

Zakres podmiotowy kontroli celno-skarbowej obejmuje wszystkie osoby prawne, osoby fizyczne, jednostki organizacyjne nieposiadające osobowości prawnej, obowiązane do przestrzegania przepisów prawa w powyżej wymienionym zakresie. Krąg kontrolowanych podmiotów zdeterminowany został więc rodzajem prowadzonej działalności i związaną z nią koniecznością przestrzegania przepisów obowiązującego prawa ${ }^{17}$. Przykładem takiej kontroli jest stosowanie sankcji karnych dla podmiotów koncesjonowanych w ramach realizacji Narodowego Celu Wskaźnikowego oraz zapisów ustawy zapasowej ${ }^{18}$. Analitycy PwC postulują, aby osoby fizyczne, które pełniły funkcje kierownicze w podmiocie, który nie wywiązywał się z NCW, powinny mieć utrudnione uzyskiwanie koncesji w kolejnych zakładanych przez nie podmiotach gospodarczych zajmujących się obrotem paliwami ${ }^{19}$. Dodatkowym postulatem jest jak największe uszczelnienie procesu wydawania nowych koncesji, uwzględnienie powyższych uchybień NCW jako przesłanek odmowy udzielenia koncesji. Kontrola celno-skarbowa według $\mathrm{PwC}$ prowadzona przez KAS oraz jednostki policji powinna być częstotliwa, obligatoryjna, kompleksowa, a przede wszystkim efektywna. Kontrola podmiotowa powinna skupiać się asymetrycznie, według czynników największego ryzyka. KAS powinien objąć kontrolą nowe podmioty gospodarcze lub takie, które krótko funkcjonują na rynku produktów akcyzowych.

Kontrola celno-skarbowa prowadzona jest przez naczelników urzędów celno-skarbowych. Jej podstawą są przepisy działu V ustawy o KAS, przy czym w zakresie nieuregulowanym, zgodnie z art. 94 ustawy o KAS, do kontroli celno-skarbowej odpowiednio stosuje się przepisy Ordynacji podatkowej, choć z pominięciem wskazanych wprost regulacji. Ponadto do kontroli celno-skarbowej nie znajdują również zastosowania przepisy ustawy z dnia 6 marca 2018 r. Prawo przedsiębiorców ${ }^{20}$. Oznacza to, że w procedurze kontroli celno-skarbowej nie będzie stosowana

16 PwC. Walka z szarą strefa. Wptyw regulacji na branżę paliw ptynnych, s. 25, http://ungc.org.pl/strefa-wiedzy/22202/ (dostęp: 31.01.2019).

17 A. Nadolska, Administracja skarbowa, w: Podstawy prawa finansowego, red. A. Drwiłło, Wolters Kluwer, Warszawa 2018, s. 255.

18 Ustawa z dnia 16 lutego 2007 r. o zapasach ropy naftowej, produktów naftowych i gazu ziemnego oraz zasadach postępowania $\mathrm{w}$ sytuacjach zagrożenia bezpieczeństwa paliwowego państwa i zakłóceń na rynku naftowym.

19 PwC. op. cit., s. 57.

20 Zob. art. 93 ustawy o KAS. Ustawa z dnia 6 marca 2018 r. Prawo przedsiębiorców (Dz. U. poz. 646 ze zm.) weszła w życie z dniem 30 kwietnia 2018 r., zastępując ustawę z dnia 2 lipca 2004 r. o swobodzie działalności gospodarczej (tekst jedn. Dz. U. z 2017 r. poz. 2168 ze zm.). 
instytucja zawiadomienia o zamiarze wszczęcia kontroli, jak również ograniczenia w jej trwaniu wskazane w tej ustawie.

Ustawa o KAS nie posługuje się terminem „kontrola celna”, funkcjonującym na gruncie unijnego oraz krajowego prawa celnego ${ }^{21}$. Niemniej jego użycie w przypadku kontroli celno-skarbowej w związku z kontrolą przestrzegania przepisów prawa celnego nie powinno być uważane za błąd. Unijne prawo celne jest bowiem stosowane bezpośrednio i jednolicie we wszystkich krajach członkowskich, a krajowe prawo celne ma tylko charakter subsydiarny w stosunku do regulacji unijnych. Jednocześnie należy dostrzec, że „kontrola celna” czy też kontrola celno-skarbowa w zakresie przestrzegania przepisów prawa celnego nie obejmuje podatków towarzyszących należnościom celnym. Chodzi o podatek VAT, akcyzę oraz opłatę paliwową ${ }^{22}$, pobierane w związku z importem towarów. Pojęcie kontroli celnej dotyczy bowiem przepisów prawa celnego, niewątpliwie zaś wymienione daniny pobierane w związku importem należnościami celnymi nie są. Stąd użyte przez autorów pojęcie kontroli celno-skarbowej obrotu towarowego z krajami spoza Unii Europejskiej dotyczyć też będzie należności podatkowych w imporcie, a w niektórych przypadkach także opłaty paliwowej. Uznając zatem za dopuszczalne stosowanie pojęcia "kontrola celna” w przypadku działań kontrolnych w zakresie obrotu z krajami trzecimi, należy pamiętać o jego zakresie znaczeniowym. Zagadnienie właściwego poboru akcyzy, definiowania zakresu jej stosowania nabrało znaczenia od wejścia w życie pakietu paliwowego w sierpniu 2016 roku. Według analityków PwC wzrostowi poboru podatku VAT o 18\% towarzyszył jedynie 5,3\% wzrost poboru akcyzy ${ }^{23}$. Należy domniemywać, że definicje rodzajów paliw wytwarzanych w rafineriach oraz importowanych paliw gotowych powodują sztuczną różnorodność kodów statystycznych, co ułatwia deklarowanie produkcji bądź importu będącego poza zakresem poboru akcyzy. Importerzy mogą deklarować import takich olejów, które nie są klasyfikowane jako olej napędowy. PwC zauważa

21 Zob. art. 5 ust. 3, art. 46-48 UKC. Polska ustawa z dnia 19 marca 2004 r. Prawo celne (tekst jedn. Dz. U. z 2018 r., poz. 176 ze zm.) posługuje się pojęciem „kontroli celnej” kilkukrotnie (art. 17, art. 20, art. 61 , art. 71, art. 96 ustawy).

22 Opłata paliwowa, której wymiar i pobór określone zostały w ustawie z dnia z dnia 27 października 1994 r. o autostradach płatnych i krajowym Funduszu Drogowym (tekst jedn. Dz.U. z 2018 r., poz. 2014 ze zm.), stanowi przychód Krajowego Funduszu Drogowego i Funduszu Kolejowego. Mimo że nie jest ona podatkiem, ma cechy podatku (zob. K. Lasiński-Sulecki, Opłata paliwowa-próba oceny zgodności z prawem Unii Europejskiej, w: Prawo celne i podatek akcyzowy..., s. 124-137. Odnośnie do określenia przez ustawodawcę organów właściwych w sprawach opłaty paliwowej zob. A. Reiwer-Kaliszewska, T. Nowak, Wtaściwość organów Krajowej Administracji Skarbowej w postępowaniu z tytułu importu towarów oraz w sprawach opłaty paliwowej, w: Prawo celne, podatek akcyzowy oraz kary pieniężne w ustawie o grach hazardowych. Doświadczenia i wyzwania, red. T. Nowak, P. Stanisławiszyn, Szczecin 2018, s. 241-247.

$23 \quad$ PwC, op. cit., s. 45. 
też, że odwróciła się dotychczasowa formuła importu paliw. Przed wejściem pakietu paliwowego deklarowano akcyzę, lecz nie VAT, a po jego wejściu deklarowano VAT, lecz nie akcyzę. Stąd wydaje się konieczne podniesienie poziomu profesjonalizmu służb statystycznych, KAS, a także Centralnego Biura Śledczego Policji (CBŚP) w celu zwiększenia kontroli fizycznych tak, aby ograniczyć ten proceder.

Wszczęcie kontroli celno-skarbowej następuje z urzędu, na podstawie upoważnienia do przeprowadzenia kontroli celno-skarbowej udzielonego kontrolującemu, natomiast datą wszczęcia jest dzień doręczenia tego upoważnienia podmiotowi kontrolowanemu. W terminie 14 dni od dnia doręczenia upoważnienia do przeprowadzenia kontroli celno-skarbowej kontrolowanemu przysługuje uprawnienie do skorygowania deklaracji w zakresie objętym tą kontrolą. Korekta deklaracji złożona po upływie tego terminu, a przed zakończeniem kontroli celno-skarbowej nie wywołuje skutków prawnych ${ }^{24}$.

Poza kontrolami realizowanymi na podstawie upoważnienia doręczanemu kontrolowanemu organy KAS dokonują również kontroli wykonywanych na podstawie okazywanej legitymacji służbowej oraz stałego upoważnienia do przeprowadzania kontroli. Dotyczy to m.in. kontroli na drogach publicznych lub wewnętrznych, w portach morskich i przystaniach, morskich wodach wewnętrznych, morzu terytorialnym, strefie przyległej lub wodach śródlądowych ${ }^{25}$. W sytuacjach "niecierpiących zwłoki” możliwe jest też wszczęcie kontroli na podstawie okazywanej legitymacji służbowej (tzw. kontrola „na legitymację") $)^{26}$.

W art. 63 ust. 1 ustawy o KAS przewidziano zasadę polegającą na tym, że kontrola celno-skarbowa powinna być zakończona bez zbędnej zwłoki, jednak nie później niż w terminie 3 miesięcy od dnia jej wszczęcia. O każdym przypadku niezakończenia kontroli celno-skarbowej we właściwym terminie zawiadamia się pisemnie kontrolowanego, podając przyczyny przedłużenia terminu zakończenia kontroli celno-skarbowej i wskazując nowy termin do jej zakończenia. Regulacja ta dozna istotnej modyfikacji w przypadku, gdy jej przedmiotem będzie weryfikacja przestrzegania przepisów prawa celnego, czyli w rozumieniu tego prawa „kontrola celna". Zgodnie bowiem z art. 63 ust. 3 ustawy o KAS 3-miesięczny termin trwania kontroli celno-skarbowej nie ma zastosowania w przypadku, gdy jest ona wykonywana m.in. na podstawie bezpośrednio stosowanych przepisów prawa UE. Kontrola celno-skarbowa w zakresie przestrzegania przepisów prawa celnego - w rozumieniu przepisów prawa celnego jest to "kontrola celna” - nie będzie zatem

24 Zob. art. 62 ust. 1, 2 i 4 ustawy o KAS.

25 Przywołane pojęcia omawia T. Nowak w: Krajowa Administracja Skarbowa. Komentarz, red. A. Melezini, K. Teszner, Wolters Kluwer, Warszawa 2018, s. 284-585.

26 Zob. art. 62 ust. 3 i 5 ustawy o KAS. 
podlegała ograniczeniom co do czasu jej trwania wynikającym z ustawy o KAS. Ograniczeń takich nie zawiera zarówno unijne, jak i krajowe prawo celne. Oczywiście czas trwania kontroli determinowany będzie zasadą ekonomiki postępowania i terminem przedawnienia.

Pewną praktyczną trudność może sprawiać wyznaczanie czasu trwania kontroli celno-skarbowej w przypadku objęcia nią zarówno należności celnych, jak i podatkowych w imporcie (oprócz podatku VAT, może też chodzić o akcyzę lub akcyzę i opłatę paliwową). Wydaje się, że w przypadku importu kontrola celno-skarbowa powinna ograniczać się do kontroli przestrzegania przepisów prawa celnego. Określenie kwoty zobowiązania podatkowego w imporcie (podatku od towarów i usług, względnie także akcyzy lub akcyzy i opłaty paliwowej) jest bowiem następstwem ustalenia wartości celnej oraz należności celnych. $\mathrm{Z}$ tego powodu należności podatkowe mogą zostać określone w postępowaniu podatkowym bez konieczności uprzedniego wszczynania kontroli celno-skarbowej w tym zakresie.

Możliwe oczywiście pozostaje wszczęcie odrębnej kontroli celno-skarbowej w zakresie należności podatkowych z tytułu importu. W przypadku wcześniejszego ustalenia wartości celnej i należności celnych nie ma jednak takiej konieczności, skoro na podstawę opodatkowania w imporcie składa się m.in. wartość celna towaru i należne cło. Jedynie w przypadku przedawnienia należności celnych, jeżeli nie przedawniły się jeszcze należności podatkowe w imporcie, gdy istnieje konieczność ustalenia podstawy opodatkowania, zasadne będzie wszczęcie kontroli celno-skarbowej w zakresie należności podatkowych z tytułu importu. Wówczas kontrola taka podlegać będzie ograniczeniom czasowym, o których mowa w art. 63 ustawy o KAS.

\section{Zadania i uprawnienia Służby Celno-Skarbowej}

Działania ustawodawcy reformującego funkcjonowanie organów w zakresie obrotu z krajami trzecimi uwzględniać musiały obowiązujące unijne prawo celne, mające charakter nadrzędny wobec prawa krajowego. Stąd zmiany wprowadzone ustawą o KAS w zakresie kontroli celnej nie są aż tak znaczące jak w przypadku kontroli należności podatkowych, aczkolwiek nie są to też zmiany tylko kosmetyczne. Przede wszystkim w ramach Krajowej Administracji Skarbowej powołana została Służba Celno-Skarbowa. Zastąpiła ona funkcjonującą dotychczas Służbę Celną. Niemniej zadania nowej formacji w zakresie przestrzegania przepisów prawa celnego oraz innych przepisów związanych z wywozem i przywozem towarów w obrocie między obszarem celnym UE a państwami trzecimi pozostały niezmienione i obejmują dwa podstawowe obszary: finansowy, związany z poborem 
i wymiarem należności celnych i podatków związanych z importem towarów oraz pozaekonomiczny, związany z kontrolą szeregu przepisów wpływających na zdrowie, życie i bezpieczeństwo mieszkańców UE. Chodzi m.in. o kontrolę przywozu zakażonej żywności i leków (np. ptasią grypą, chorobą wściekłych krów), ochronę dóbr kultury, własności intelektualnej i znaków towarowych (kontrola importu tzw. podróbek), a także zagrożonych wymarciem chronionych gatunków roślin i zwierzą ${ }^{27}$. W zakresie kompetencji kontroli celno-skarbowej jest więc szerokie spektrum regulacji począwszy od przepisów sanitarnych po regulacje dotyczące bezpieczeństwa i obronności. Zmianie uległa natomiast formalna strona dokumentowania przeprowadzonej kontroli celno-skarbowej w zakresie przestrzegania przepisów prawa celnego. Ustawodawca wprowadził zasadę (art. 84 ust. 1 w zw. z art. 54 ust. 1 pkt. 2 ustawy o KAS), zgodnie z którą kontrola celno-skarbowa w zakresie prawa celnego oraz innych przepisów związanych z przywozem lub wywozem towarów w obrocie między obszarem celnym UE a państwami trzecimi kończy się protokołem. Pozwala to, w zależności od treści protokołu, na podjęcie decyzji o sposobie dalszego działania w sprawie, np. poprzez wszczęcie postępowania celnego. Ów protokół powinien zawierać w szczególności wskazanie kontrolowanego i kontrolującego, określenie przedmiotu i zakresu kontroli celno-skarbowej, określenie miejsca i czasu przeprowadzenia kontroli celno-skarbowej, opis dokonanych ustaleń faktycznych oraz dokumentację dotyczącą przeprowadzonych dowodów.

Niejasny pozostaje jednak tryb postępowania naczelnika urzędu celno-skarbowego przeprowadzającego kontrolę celno-skarbową wobec podatku od towarów i usług z tytułu importu (ewentualnie także akcyzy lub akcyzy i opłaty paliwowej). Jak już wskazano powyżej, nie są to należności celne. Nie podlegają więc kontroli przestrzegania przepisów prawa celnego i jako takie powinny być przedmiotem kontroli przestrzegania przepisów prawa podatkowego. Literalne brzmienie art. 54 ust. 1 pkt 1 ustawy o KAS dopuszcza zatem przeprowadzenie kontroli celno-skarbowej w zakresie podatków w imporcie. Uwzględniając dodatkowo treść art. 61 ustawy o KAS, zgodnie z którym naczelnik urzędu celno-skarbowego może wykonywać kontrolę celno-skarbową na całym terytorium Rzeczypospolitej Polskiej, można z przepisów ustawy o KAS wywieść uprawnienie naczelnika urzędu celno-skarbowego do wykonywania kontroli celno-skarbowej w zakresie podatków $\mathrm{w}$ imporcie na terytorium całego kraju.

27 I. Sobczyk, Ochrona i bezpieczeństwo obszaru celnego Wspólnoty Europejskiej w zadaniach $i$ kompetencjach Stużby Celnej, w: Bezpieczeństwo w administracji i biznesie we wspótczesnym świecie, red. M. Chrabkowski, C. Tatarczuk, J. Tomaszewski, Wyższa Szkoła Administracji i Biznesu im. E. Kwiatkowskiego w Gdyni, Gdynia 2011, s. 182-183. 
Zaproponowana wykładnia wskazanych przepisów ustawy o KAS powinna jednak zostać zweryfikowana poprzez konfrontację z regulacjami ustawy o podatku od towarów i usług oraz ustawy o podatku akcyzowym w wypadku importu towaru ${ }^{28}$. Zasadniczo podatnicy są obowiązani do obliczenia i wykazania w zgłoszeniu celnym kwoty podatku, z uwzględnieniem obowiązujących stawek (art. 33 ust. 1 u.p.t.u. oraz art. 27 ust. 1 u.p.a.). Jeżeli przed zwolnieniem towaru ujawniona zostanie nieprawidłowość odnośnie do zadeklarowanej kwoty podatku VAT, naczelnik urzędu celno-skarbowego, który przyjął zgłoszenie celne, zadziała z urzędu i wyda decyzję określającą podatek w prawidłowej wysokości (art. 33 ust. 2 u.p.t.u. oraz art. 27 ust. 4 u.p.a.) lub - jeśli podatnik „zareaguje” szybciej - naczelnik rzędu celno-skarbowego wyda decyzję określającą podatek w prawidłowej wysokości na wniosek podatnika.

Po zwolnieniu towaru kwotę podatku należnego z tytułu importu towarów określa naczelnik urzędu celno-skarbowego w drodze decyzji (art. 34 u.p.t.u. oraz art. 27 ust. 6 u.p.a). Również gdy, zgodnie z przepisami celnymi, powiadomienie dłużnika o wysokości długu celnego nie może nastąpić z uwagi na przedawnienie, a nie upłynęło 5 lat, licząc od końca roku kalendarzowego, w którym powstał obowiązek podatkowy z tytułu importu towarów i istnieje podstawa do obliczenia lub zweryfikowania należności podatkowych, naczelnik urzędu celno-skarbowego może określić elementy kalkulacyjne według zasad określonych w przepisach celnych na potrzeby prawidłowego określenia należnego podatku z tytułu importu towarów (art. 38 ust. 2 u.p.t.u. oraz art. 29 u.p.a.).

Wskazany na gruncie ustawy o podatku od towarów i usług oraz ustawy o podatku akcyzowym tryb korekty zgłoszenia celnego wyklucza więc możliwość złożenia korekty, o której mowa w art. 62 ust 4 oraz art. 82 ust. 3 ustawy o KAS. Zauważmy bowiem, że w przypadku kontroli celno-skarbowej w zakresie prawa podatkowego organ nie sporządza protokołu, a wynik kontroli. Różnica jest istotna, gdyż zgodnie z art. 82 ust. 3 ustawy o KAS kontrolowany może w terminie 14 dni od dnia doręczenia wyniku kontroli skorygować uprzednio złożoną deklarację podatkową i uniknąć - jeśli organ uwzględni złożoną korektę - prowadzenia postepowania podatkowego.

Należałoby się zatem opowiedzieć za poglądem, że choć podatek od towarów i usług oraz podatek akcyzowy w imporcie nie są należnościami celnymi, to jednak powinny być wobec nich stosowane zasady kontroli celno-skarbowej, o których mowa w art. 54 ust. 1 pkt. 2 ustawy o KAS, czyli zasady właściwe dla kontroli

28 Zob. art. 33-40 ustawy z dnia 11 marca 2004 r. o podatku od towarów i usług (tekst jedn. Dz. U. z 2018 r., poz. 2174 ze zm., dalej: u.p.t.u.) oraz art. 27-29a ustawy z dnia o podatku akcyzowym (tekst jedn. Dz. U z 2018 r., poz. 1114 ze zm., dalej: u.p.a.). 
przestrzegania przepisów prawa celnego. Przemawia też za tym - dostrzeżona w piśmiennictwie - reguła upodabniania się regulacji podatkowych do przepisów prawa celnego w wypadku łącznego stosowania przepisów celnych i podatkowych (por. m.in. art. 147a o.p.; art. 34 ust. 2 ustawy o pod. VAT; art. 28 ust. 1 ustawy o pod. akc. $)^{29}$. Nie bez znaczenia pozostaje też postulat prowadzenia postępowania w sposób skuteczny i bez przewlekłości, co zapewnić może organ, który przyjął zgłoszenie celne.

Nieco inaczej wygląda deklarowanie w związku z importem kwoty należnej opłaty paliwowej. Nie jest ona deklarowana w zgłoszeniu celnym, ale w informacji w sprawie opłaty paliwowej składanej według wzoru określonego w rozporządzeniu Ministra Finansó $w^{30} \mathrm{w}$ terminie określonym dla należności celnych do naczelnika urzędu celno-skarbowego właściwego ze względu na miejsce powstania długu celnego. W przypadku ujawnienia nieprawidłowości w deklaracji kwoty opłaty paliwowej należnej z tytułu importu tenże naczelnik urzędu celno-skarbowego obowiązany będzie do wszczęcia postępowania w sprawie i określenia prawidłowej kwoty zobowiązania w opłacie paliwowej w związku z importem towaru. Podobnie jak w przypadku podatków z tytułu importu kontrola celno-skarbowa w zakresie opłaty paliwowej powinna być zatem prowadzona na zasadach właściwych dla kontroli celno-skarbowej w zakresie przestrzegania przepisów prawa celnego. Dodać można, że postępowanie w sprawie określenia prawidłowej kwoty opłaty paliwowej z tytułu importu prowadzone będzie na podstawie przepisów Ordynacji podatkowej z uwzględnieniem zmian wynikających z ustawy o autostradach płatnych i krajowym Funduszu drogowym, bowiem do opłaty paliwowej stosuje się odpowiednio przepisy Ordynacji podatkowej ${ }^{31}$.

Doświadczenie Służby Celno-Skarbowej, a wcześniej Służby Celnej, należałoby też wykorzystać do zaostrzenia trybu kontroli wwozu na terytorium Rzeczpospolitej wyrobów akcyzowych z krajów trzecich, w których wyroby takie nie są obciążone akcyzą. Obniżyłoby to ryzyko ich wwozu na teren Unii Europejskiej przez jednostki funkcjonujące w szarej strefie. Wykorzystują one brak pełnej harmonizacji w zakresie podatku akcyzowego w krajach Unii Europejskiej ${ }^{32}$. Równolegle

29 Zob. K. Lasiński-Sulecki, Umowy w sprawie unikania podwójnego opodatkowania a prawo celne. Wybrane zagadnienia (w:) Regulacje w zakresie prawa celnego i podatku akcyzowego po przystapieniu Polski do Unii Europejskiej. Doświadczenia i perspektywy, red. P. Stanisławiszyn, T. Nowak, Warszawa 2012, s. 295-296.

30 Zob. Rozp. MF z dnia z dnia 16 sierpnia 2017 r. w sprawie określenia wzoru informacji w sprawie opłaty paliwowej (Dz. U. poz. 1671).

31 Artykuł 37q ustawy z dnia 27 października 1994 r. o autostradach płatnych krajowym Funduszu Drogowym.

32 W Polsce obłożono oleje mineralne (CN 2710) akcyzą stawką 1180 zl/1000 litrów, a oleje smarowe syntetyczne nie (CN3403). Nowa stawka akcyzy mogłaby zostać obliczona jako średnia ważona, 
należałoby rozważyć zwiększenie kontroli importu do Polski oraz obrotu olejami przepracowanymi i odpadowymi, których import ogranicza poziom konsumpcji legalnych olejów opałowych oraz przyczynia się do zanieczyszczania środowiska naturalnego, a także jest wprost złamaniem polskich przepisów akcyzowych ${ }^{33}$. Prace legislacyjne w Unii Europejskiej dotyczące uaktualnienia Ramowej Dyrektywy Odpadowej podążają w kierunku obrotu olejami odpadowymi w ramach gospodarki zamkniętej, co wymaga zdecydowanego zwiększenia poziomu zbiórki olejów, obowiązku recyklingu olejów odpadowych, a także kontroli celno-skarbowej monitorującej i sprawdzającej fizyczne przemieszczanie się tych ładunków zarówno przez granice zewnętrzne Unii Europejskiej, jak i przemieszczenie transgraniczne między państwami członkowskimi UE ${ }^{34}$. Proaktywne działania KAS powinny objacć predykcyjny monitoring ofert handlowych na platformach internetowych w tym zakresie, zanim nastąpi przemieszczenie olejów odpadowych oraz przepracowanych oraz dodatkowo objęcie przemieszczenia olejów w Systemie Przemieszczania oraz Nadzoru Wyrobów Akcyzowych EMCS (Excise Movement and Control System) w całej Unii Europejskiej ${ }^{35}$.

\section{Podsumowanie}

Przeprowadzona w 2017 roku reforma KAS jest pierwszym krokiem w kierunku zwiększenia kontroli państwa nad poborem należności celnych oraz innych opłat związanych z przywozem towarów spoza UE. W wyniku uchwalenia pakietu energetycznego oraz paliwowego w 2017 roku, a także usprawnienia działania KAS, oficjalny import paliw ciekłych w 2017 roku wzrósł o 2,2 $\mathrm{mln} \mathrm{m}^{3}$, czyli o $24 \%$ względem 2016 roku ${ }^{36}$. Poważnym zagrożeniem funkcjonowania KAS jest opóźnienie dotyczące wdrożenia nowych standardów kontroli celno-skarbowej przez wprowadzenie obowiązku proaktywnego i predykcyjnego monitoringu ofert importowych w obszarze towarów wrażliwych, mogących być przedmiotem nie-

tak aby łączne obciążenie akcyzą obu rodzajów importowanych olejów smarowych pozostało bez zmian. Polska Organizacja Przemysłu i Handlu Naftowego (POPiHN), Raport roczny 2017, Przemyst $i$ handel naftowy, Warszawa 2018, s. 9, http://www.popihn.pl/raporty2.php (dostęp: 16.10.2018).

33 Polska Organizacja Przemysłu i Handlu Naftowego (POPiHN), op. cit., s. 9.

34 Konieczność oraz sposoby recyklingu olejów odpadowych oraz ich transportu zostały określone w dyrektywie UE 2008/98/WE z dnia 19 listopada 2008 r. w sprawie odpadów oraz uchylająca niektóre dyrektywy, https://eur-lex.europa.eu/legal-content/pl/TXT/?uri=CELEX:32008L0098 (dostęp 18.10.2018).

35 Polska Organizacja Przemysłu i Handlu Naftowego (POPiHN), op. cit., s. 9.

36 Ibidem. 
legalnego wwozu na teren UE z pominięciem kontyngentów ilościowych nie tylko w obszarze paliw płynnych (import towarów poza oficjalnym kontyngentem UE), opłaty akcyzowej, paliwowej czy podatku VAT.

Postulatem de lege ferenda byłaby nowelizacja ustawy o KAS wskazująca wyraźnie, że kontrola celno-skarbowa w zakresie podatków (w tym opłaty paliwowej) w imporcie kończy się - jak wypadku kontroli w zakresie przestrzegania przepisów prawa celnego - protokołem. Nie byłoby wówczas wątpliwości, że ewentualne postępowanie podatkowe w zakresie podatku z tytułu importu powinien prowadzić organ, który przyjął zgłoszenie celne.

Zwiększenie skuteczności KAS powinno być wielowymiarowe i wdrażane z myślą skutecznego stosowania prawa. Należy nie tylko ograniczyć zakres szarej strefy, wzmacniać warunki uczciwej gry rynkowej legalnie zarejestrowanych podmiotów gospodarczych, lecz również systematycznie poprawić sytuację dochodów własnych Skarbu Państwa.

\section{Bibliografia}

Lasiński-Sulecki K., Opłata paliwowa - próba oceny zgodności z prawem Unii Europejskiej, w: Prawo celne i podatek akcyzowy. Kierunki przeobrażeń i zmian, red. P. Stanisławiszyn, T. Nowak, Warszawa 2014.

Lasiński-Sulecki K., Umowy w sprawie unikania podwójnego opodatkowania a prawo celne. Wybrane zagadnienia, w: Regulacje w zakresie prawa celnego i podatku akcyzowego po przystapieniu Polski do Unii Europejskiej. Doświadczenia i perspektywy, red. P. Stanisławiszyn, T. Nowak, Warszawa 2012.

Melezini A., w: Krajowa Administracja Skarbowa. Komentarz, red. A. Melezini, K. Teszner, Wolters Kluwer, Warszawa 2018.

Nadolska A., Administracja skarbowa, w: Podstawy prawa finansowego, red. A. Drwiłło, Wolters Kluwer, Warszawa 2018.

Nowak T., w: Krajowa Administracja Skarbowa. Komentarz, red. A. Melezini, K. Teszner, Wolters Kluwer, Warszawa 2018.

Piech K., Procedura tranzytu jako pierwowzór procedury zawieszenia poboru akcyzy. O zwiazkach prawa akcyzowego z prawem celnym na podstawie doświadczeń niektórych państw członkowskich Unii Europejskiej, w: Prawo celne i podatek akcyzowy. Kierunki przeobrażeń $i$ zmian, red. P. Stanisławiszyn, T. Nowak, Warszawa 2014.

Polska Organizacja Przemysłu i Handlu Naftowego (POPiHN), Raport roczny 2017, Przemyst $i$ handel naftowy, Warszawa 2018, http://www.popihn.pl/raporty2.php (dostęp: 16.10.2018).

PwC, Walka z szara strefa. Wpływ regulacji na branżę paliw ptynnych, http://ungc.org.pl/ strefa-wiedzy/22202/ 
Reiwer-Kaliszewska A., Nowak T., Właściwość organów Krajowej Administracji Skarbowej w postępowaniu z tytulu importu towarów oraz w sprawach opłaty paliwowej, w: Prawo celne, podatek akcyzowy oraz kary pieniężne w ustawie o grach hazardowych. Doświadczenia i wyzwania, red. T. Nowak, P. Stanisławiszyn, Szczecin 2018.

Sobczyk I., Ochrona i bezpieczeństwo obszaru celnego Wspólnoty Europejskiej w zadaniach i kompetencjach Stużby Celnej, w: Bezpieczeństwo w administracji i biznesie we współczesnym świecie, red. M. Chrabkowski, C. Tatarczuk, J. Tomaszewski, Wyższa Szkoła Administracji i Biznesu im. Eugeniusza Kwiatkowskiego w Gdyni, Gdynia 2011. 